\title{
1 Introduction: Minsky on money, banking and finance
}

\author{
Dimitri B. Papadimitriou and L. Randall Wray
}

The genesis of this Companion to Minsky was the republication, in 2008, of Minsky's two seminal books: John Maynard Keynes and Stabilizing an Unstable Economy first published in 1975 and 1986 respectively. Introducing Minsky to the wider world, the Wall Street Journal wrote: 'Hyman Minsky spent much of his career advancing the idea that financial systems are inherently susceptible to bouts of speculation that, if they last long enough, end in crises ... Indeed, the Minsky Moment has become a catch phrase on Wall Street.' There is, then, hardly any need to comment on the relevance of Hyman Minsky's work to the global financial and economic crisis that began in 2007 in the US and quickly spread around the world. Several of the chapters in this volume explicitly take up that topic. Many more economists have, recently, discovered Minsky's Financial Instability Hypothesis (FIH) and widely applied it to the course of events in the US from 2004 until the real estate market went bust, and many commentators used his hedge, speculative, and Ponzi classification scheme to analyze the evolution of mortgage markets. Many of Minsky's favorite themes - 'stability is destabilizing', the role of the 'Big Government' and 'Big Bank' in constraining endogenous instability, banker's rationality, money non-neutrality, creative destruction and innovation by financial institutions - are taken up in the chapters especially written for this companion to Minsky. This introductory chapter does not summarize those that follow, but in a few sentences attempts to demonstrate how each chapter connects to Minsky's core ideas. The reader will need to go to each contribution to discover its individual message.

In an earlier period, Minsky wrote concerning the devastating consequences that would take place on the balance sheets of households and businesses, and especially on financial institutions carrying mortgage debt should the price of real estate assets fall sharply (Minsky 1964). As Jan Kregel points out in the next chapter, this concern was voiced in the 1960s, when Minsky analyzed the then fragile financial environment and offered clear policy prescriptions that should be implemented by the central bank and more crucially by the authorities responsible for managing fiscal policy. Little did he know how prescient his writings of more than four 
decades would be in August 2007, when the housing markets meltdown began. Minsky's analysis of the 1960s and the policy suggestions he made are the focus of this chapter as are the lessons that can be drawn from that period and their applicability in responding to the challenges of the current financial and economic crisis. Apt fiscal policy was very important to Minsky's thinking and his writings over the years reflect it (Minsky 1986 [2008], 1992). As he put it, an economy, to prosper, needed not only a 'Big Bank,' acting as a lender of last resort, but also a 'Big Government.' He was particularly concerned with simple and erroneous interpretations of 'Big Government' being synonymous with Keynesian fine-tuning of aggregate demand rather than associated with a structuralist approach ensuring stability and full employment and interacting with the private sector. Éric Tymoigne explores these important Minskyan connections with considerable detail in Chapter 3 and places them in a US historical perspective. These issues are also discussed and analyzed further by Bellofiore, Halevi and Passarella from an alternative perspective in Chapter 4. The authors of this chapter contextualize and document the relevance of Minsky's ideas of 'Financial Keynesianism' and 'Wall Street Paradigm' in contemporary forms of capitalism. An analysis of the Minskyan banker is offered in Chapter 5 by Eric Nasica aiming at explaining bankers' rationality contributing to pro-cyclical financial fragility in concert with Minsky's FIH. The underlying theme is banks' entrepreneurial and innovative behaviors being the cause of institutional weakening and the transitioning of a financially overleveraged system to a state of financial crisis. This is Minsky's banking theory.

In Chapter 6, Auerback, McCulley and Parenteau attempt to answer the question 'What would Minsky do?' in the current crisis. Their answer is deep rooted in Minsky's work on financial instability as a function of ever increasing risk, the institutional structure, organization of regulation and supervision of institutions and markets and the policy responses as proposed by Minsky sometime ago.

Minsky was not comfortable with mainstream economics, especially with its emphasis and use of mathematics to analyze and establish elusive theoretical concepts such as general equilibrium. He was more interested in the structural, social and political aspects of the discipline as they were represented by the institutional design of an economy. Barbera and Weise, accepting Minsky's suspicions of mathematical formalization, attempt, nevertheless, to create a Minsky warning structure of asset inflation by modifying the standard Taylor rule of monetary policy determining the federal funds rate. In Chapter 7, they develop an expanded Taylor rule relationship they call Minsky/Wicksell Modified Taylor Rule (MWMTR) grounded on Minsky's insights of increasing leverage and 
risk that can detect undue asset price increases. Their aim is to make it easier for economists and central bankers to embrace a Minsky model they understand. Minsky was well aware of the importance of the link between innovation and finance, and how this relation affects stability in modern and financially guided economies. He understood that innovation processes emanating from financial institutions could not be explained very well by formal theory since they were the creation of human beings and uncontrolled markets, but he insisted that they be designed and managed in such a manner as to ensure economic stability. Martin Shubik, in Chapter 8, considers these connections and the 'mechanisms for the creation of money and credit, the selection of innovation' and the mix of institutional form and function using simple but detailed models. Duncan Foley, in Chapter 9, agrees to a large extent with Shubik echoing his assessment of Minsky's refusal to articulate his insights on financial instability inherent in the financial dynamics of a contemporary capitalist economy using the rigor of a mathematical model. As Foley points out, Minsky's dialectical investigation of his FIH is validated from historical patterns linked to detailed institutional reality and the unfolding of particular incidents of financial crisis. And even though his ideas and penetrating analysis provided no alternative to the contemporary economic method, they nevertheless, found resonance in the worlds of finance and policymaking.

Many of Minsky's followers have attempted to transform his vision in the language of mathematical and econometric modeling with varying success. The latest examples are found in the work of Assenza, Delli Gatti and Gallegati, and Ferri, the focus of Chapters 10 and 11 respectively. The authors of Chapter 10 construct a macrodynamic model of firm specific financial conditions including behavioral characteristics of financially constrained firms and households to determine instability. The derived dynamics from their model are dependent on the laws of motion emanating from particular financial conditions of individual heterogeneous agents and, using computer simulations, they analyze the evolution of micro and macro state variables. They also contrast their results with those of the Financial Accelerator research they consider to some extent akin to Minsky. Piero Ferri's goal, in Chapter 11, is also the formalization of Minsky's financial instability, but he wants to determine under what conditions of endogenously generated fluctuations the system can reach a breaking point. The mathematical narrative of his approach, much more advanced than previously (Ferri 1992), is the specification of a nonlinear dynamic model that tests and simulates debt dependent aggregate demand and supply subject to conditions of bounded rationality. The policy implications determined by the model are contrasted with historical episodes 
in the US and other countries, and further advances in this lineage of modeling research are suggested.

Booms and busts are spatial with high levels of uncertainty in exchange rate conditions impacting investment-financing processes across country borders. Indeed, the global imbalances since the 1980s, with the US being the chronic current account deficit economy financed by the current account surplus emerging market economies in Asia, most notably China, have had serious implications in the development of the current economic and financial crisis in the US and the global economy (Godley et al. 2006). Minsky's framework has been principally applied in an environment that assumes the financial cycle develops and affects a closed and homogeneous economy. Gary Dymski, in Chapter 12, extends the Minskyan core model to an open economy framework. Financial instability and crisis, as Dymski documents, can be dependent on the real and financial tensions inherent in capital flows across countries and can develop even in the absence of a typical Minsky cycle, which has implications for policy responses.

Behavioral finance was not specifically acknowledged in Minsky's writings, even though, as Sheila Dow suggests in Chapter 13, his uncertaintybased epistemology and method viewed from the lens of psychology can enhance our understanding of financial instability. There is a lot of psychological content in Minsky, since it is behavior that leads up to financial turmoil and market responses to it. In behavioral finance, however, she finds a lacuna relating to the motivation for action under uncertainty that plays a crucial part in Minsky's FIH and his mentor's (Keynes) treatment of financial behavior. Dow also explores the effects of uncertainty and emotion at the level of social structures and institutions as they are recognized in Minsky's structural approach.

This companion to Minsky ends with the essay by Galbraith and Munevar Sastre (Chapter 14), which departs from the other chapters, including this introduction, in that it considers a more 'generalized "Minsky Moment" by applying it to other areas of social science, as for example, the sphere of international relations. What Galbraith and Munevar do quite brilliantly is to develop 'an analytical framework that may help describe the economic, political and military interactions of nation states' according to Minsky's taxonomy of financing profiles: hedge, speculative and Ponzi.

What we want to do in the remainder of this chapter is to take a longer-run perspective. Rather than addressing the evolution of financial positions over the course of a cycle, we will use Minsky's framework to examine how the financial system evolved over the entire post-war period, from one that promoted stability to one that was much more fragile. Of course, over those six decades, there were many business cycles and a 
number of (increasingly frequent and severe) financial crises. Each one of these is worthy of a Minskyan analysis. In what follows, we will look at a few of these (with more attention paid to the first postwar financial crisis the municipal bond crisis of the mid-1960s - before turning in some detail to the current global financial crisis of 2007-10). Our purpose, however, is to take stock of the longer-term trend rather than to provide a close analysis of any particular cycle or crisis. Minsky took it for granted that the fundamental instability of the modern capitalist economy is upward - that is, toward a euphoric boom - however, each speculative frenzy is unique, and the events that bring a boom to an end are specific. In other words, Minsky's analysis was always institutional and historical. Still, there are common features involved: innovations, rising leverage, and - most significantly - changes to the 'model of the model' used by households, firms, banks, and even governments to form expectations. Decision-making always takes place in the context of fundamental uncertainty, so that the 'emotions' identified by Sheila Dow in Chapter 13 are important. These underlie the margins of safety built into financial arrangements. And because institutional 'ceilings and floors' contained the thrust toward depression (at least until the current crisis), there has been a long-term, endogenously induced trend toward closer concatenation of prospective income flows and contracted payments. Finally, those institutions that constrained instability have been seriously eroded by a combination of profit-seeking innovation plus relaxed regulation and supervision by governmental institutions. Thus, the current crisis was in some sense inevitable, although the precise timing and what triggered it could have been almost anything.

In this chapter, we analyze what Minsky (1964) referred to as a 'longer wave' - a long-term swing that is due to cumulative changes in the financial variables. The exact evolution of the financial variables over a longer wave depends on initial conditions and institutional arrangements (both market arrangements as well as legislated arrangements). The longer wave takes place over a succession of shorter, mild, recession cycles. Over the course of a long wave expansion, assets get revalued and financial layering rises. Debt grows relative to outside money - high power money (HPM), stretching liquidity; further, it grows relative to the income required to service it (so debt to gross domestic product (GDP) ratios grow on trend). In addition, stock prices and real estate prices will also grow on trend. As these grow, this generates (largely unrealized) capital gains that can be used for additional borrowing, increasing leveraging. Further, over the expansion, government debt (and HPM) tends to grow more slowly than GDP, increasing fragility. All of these characteristics apply to the long wave expansion of the post-war period. Minsky argued that as this 
long wave continues, the maximum combination of income shortfalls and defaults that can be safely handled falls. This is because more of the income flows are pre-committed, and layering of debt rises (so that default by one leads to a snowball of defaults). A panic can occur when income falls or defaults rise. Beyond some point, the 'Big Government' and 'Big Bank' stabilizers might not be sufficient to prevent 'It' (a debt deflation) from occurring. It is possible that the crisis that began in late 2007 will end the post-war long wave.

The chapter is organized as follows: first, we examine Schumpeter's profound influence on Minsky, while in the next section, we look at the nature of a system dominated by commercial banks, the emphasis that both Schumpeter and Minsky placed on them and their role in financial innovation and the capital development of an economy. We then move to analyze the first significant financial trauma since the 1930s, the Credit Crunch of 1966, which involved a run on a financial instrument or institution without a specific case of a failure or fraud. We next examine the great Monetarist Experiment and its long-term impact on the financial sector setting the stage for the current crisis. The practice of securitization as a new way of finance and the dominant role it played in the current global economic collapse is the focus of the subsequent section followed by a section on what form a Minskyan reconstitution of the financial system will take. In the concluding section, we draw lessons from Minsky that are applicable for the current crisis.

\section{Schumpeterian finance and innovation}

Minsky always insisted that any student who wanted to understand his views on finance would first have to master Schumpeter's theory of economic development. (Schumpeter was Minsky's original dissertation advisor.) According to Minsky, Schumpeter successfully integrated financial entrepreneurship and financial evolution into his analysis of economic development.

The nature of such a 'Schumpeterian' system is dominated by commercial banks. In Schumpeterian terms the banker was the 'ephor' of capitalism. Schumpeter begins with an economy operating in the neighborhood of a 'general' equilibrium in which all industries, firms, and households are individually in a state of equilibrium in the Walrasian sense (Schumpeter 1944). In this state, the economy can be analyzed as a circular flow, where purchases of the output flow are undertaken on the basis of sales of labor, products, or services, but the flow for purchases without sales or sales without purchases is ruled out. In this case, the circular flow could continue unchanging as 'the circulation of the blood' (Schumpeter 1934 [1949], p. 61). While money might be used in the circular flow economy, it 
would be used merely to facilitate exchange; it would function only as a veil. Within a circular flow, individuals can act promptly and rationally; behavior can be the result of cold calculation of probabilistic outcome. The capitalist is merely a manager, reacting to the 'data' ground out by the circular flow economy.

Of course, no society would in practice remain static. Some changes can be analyzed as continuous, infinitesimal shocks to the circular flow that lead to new points of equilibrium. Schumpeter's focus, however, is on 'that kind of change arising from within the system which so displaces its equilibrium point that the new one cannot be reached from the old one by infinitesimal steps' (Schumpeter 1934 [1949], p. 64), that is, spontaneous, discontinuous, and revolutionary changes to the circular flow that displace it so far from equilibrium that adaptation becomes impossible and routine must be abandoned. This is what he calls economic development, the result of innovation, characterized as the carrying out of new combinations of materials and forces or productive means.

Entrepreneurial innovation breaks the norm of the circular flow since it requires purchase without sale; it requires use of money as a 'claim ticket' on productive resources without use of money as a 'receipt voucher' for sale of commodities or services (Bellofiore 1985, 1992). Just as the circular flow is broken by innovation, the neutrality of money is broken by entrepreneurial activity; indeed, economic development requires non-neutrality of money.

Schumpeter believed that the strongest case could be made on the assumption that within a circular flow, all resources are fully utilized. This means that the innovator must draw already employed resources from the circular flow and direct them to a new and revolutionary activity (Schumpeter 1934 [1949], p.68). This requires creation of new purchasing power, which can only come from credit creation. Innovation, then, requires a credit system, and the credit system is a result of this necessity. The banker is the 'capitalist par excellence', the 'ephor' of the capitalist system, as he/she produces "the commodity "purchasing power" that makes it possible to carry out the new combinations associated with innovation (Schumpeter 1934 [1949], p. 74).

Since credit allows purchase without sale (of previously produced goods and services), it can be inflationary as innovators outbid resources in order to use them in the new combinations. The 'old' firms will command fewer resources and their output may well fall. Purchases of resources by the innovators, however, maintain aggregate demand even as aggregate supply falls, resulting in what Schumpeter calls temporary credit inflation. After some period (which can take several years), the new combinations can finally put products into the market while at the same time the sales 
receipts of new firms enable them to retire the credit initially advanced to allow the innovation to proceed. As a result, loans and deposits ('money supply') contract toward the initial position, and spending power and prices also fall back toward initial levels (Schumpeter 1944, p.9). Thus, the credit inflation is only temporary, and the innovation can even lead to a deflationary longer-term trend or bias as it reduces costs of production (Schumpeter 1934 [1949], p. 111).

Schumpeter calls 'primary wave' the period during which the economy first moves away from the circular flow in an expansion, but then contracts back toward the initial equilibrium of the circular flow even with no expectational errors. However, as firms are likely to react to rates of change, the initial expansion of purchasing power (and inflation of prices) can lead to a boom driven by 'mass psychology', while the contraction can degenerate to recession as the economy overshoots the circular flow on the way down. These 'secondary waves' increase the instability that is inherent in the capitalist economy (an often used theme in Minsky's work).

Innovation, itself, is endogenously generated by the apparent tranquility of the circular flow. That is, within a circular flow, the capitalist is sure of his ground and can adjust conduct in response to economic data. This confidence, however, raises entrepreneurial spirits, inducing experimentation and encouraging innovation (Bellofiore 1992). Innovation, in turn, generates expansion and disrupts conventional patterns of behavior; it becomes too difficult to make predictions and entrepreneurial spirit is depressed. As Schumpeter argues, the innovation "changes social and economic situations for good' as it alters the data of the system and moves it away from equilibrium, and makes it impossible - even for the new entrepreneurs - to predict the outcome of actions (Schumpeter 1951, p.217; Bellofiore 1992). All of these themes can also be found in Minsky's work the importance of innovations as well as the role that apparent tranquility plays in generating them.

According to Schumpeter, when new innovations stop coming forward the economy turns downward; it eventually returns to a circular flow of reproduction. Schumpeter argues that lack of inventions is never the barrier to innovation; rather, it is the lack of entrepreneurial spirit that would put the inventions to use in innovative ways that is the barrier to economic development. Once a circular flow has operated near equilibrium for a sufficient period, confidence will be restored sufficiently that innovation may reappear.

Minsky, in concert with Schumpeter, maintained that economies with financial innovations are subject to booms and busts because these innovations allow debt to increase faster than ability to pay, and because they shift income to the rentier class with a lower propensity to spend (thus, 
lowering the aggregate demand that would be necessary to continue to generate the income necessary to service debt). The strong influence of Schumpeter's many theoretical elements are clearly evident in Minsky's approach: importance of finance; endogenously induced innovations; and cyclical behavior responding to outcomes even as it influences outcomes. Minsky paid a lot of attention to commercial banking, and to this we turn next. In the early post-war period, the commercial banker was, indeed, the 'ephor' of capitalism, but that position was systematically eroded as 'managed money' took on a dominant role.

\section{Minsky on commercial banking: reserves, loans and deposits}

Minsky used to argue that anyone can create money - the problem is to have it accepted. This statement makes it clear that he identified 'money' with an IOU, and what he meant was that anyone can issue an IOU denominated in the money of account (dollar in the US), but some find more 'takers' for their IOUs. Indeed, he recognized a 'hierarchical' or 'pyramid' of money IOUs ranked according to acceptability, with the government's own IOUs at the top, then those of commercial banks, next the liabilities of other types of financial institutions, and finally the IOUs of nonfinancial firms as well as households at the bottom. Further, the IOUs of those lower in the pyramid are normally 'redeemed' for those higher in the pyramid; another way of stating it is to say that one usually extinguishes one's liability by payment of a liability issued by an entity higher in the pyramid. In this section we will focus on the commercial bank sector because commercial banks traditionally played the most important role in providing finance for businesses, households, and even state and local government loans. Over time, as we discuss later, they were displaced by other types of financial institutions and instruments - what we used to call 'nonbank banks', although they are now frequently referred to as the 'shadow banking sector'. In this section, when we write 'bank', we mean 'commercial bank' as defined by the Glass-Steagall Act that separated commercial banking from investment banking - institutions that both accepted deposits and made loans. We will identify the essential characteristics to indicate why Schumpeter placed so much emphasis on them.

Following Minsky, we too reject the old notion of a deposit multiplier in which banks wait until they have excess reserves to make loans and issue deposits. That view essentially regarded bank reserves as a sort of 'raw material' used by banks subject to fractional reserve laws to 'manufacture' loans and deposits. Thus, the bank would try to attract a deposit so that it could make a loan; or, it would look to the Fed to provide reserves so that the bank could lend any excess reserves - with the system as a whole 
creating a multiple expansion of deposits and loans. Even in his earliest writings, Minsky (1957) realized this was far too simplistic because banks actively innovate in order to throw off reserve constraints. He discussed how the creation of the federal funds market as well as other innovations allowed a given quantity of reserves to support more loans and deposits. Later, he explicitly adopted the view that banks 'endogenously' create loans and deposits and then seek reserves as necessary from the central bank. Here we will discuss how commercial banks actually operate.

First, it is critical to understand that bank deposits are liabilities; while this may seem too obvious to warrant mention, casual discussion of bank operations often neglects to consider that a deposit makes a bank liable for something. The bank is liable for high power money (HPM - reserves and cash). Deposits are simply a 'horizontal' leveraging of HPM - a promise to deliver HPM according to the contractual agreement (on demand in the case of demand deposits, on a specific future date in the case of a time deposit). Effectively, the bank is short of HPM, betting it will be able to obtain the necessary HPM in a timely manner at a not-too-prohibitive cost. Reserve requirements are simply minimum HPM balance requirements, much as many readers are forced to maintain a thousand dollars in their checking accounts. These in no direct way constrain the bank's ability to 'make loans', although they raise the bank cost of shorting HPM (much as compensating balance requirements raise the cost to a firm of taking out a bank loan - shorting bank money), thus, may increase the return that must be obtained on assets to make them desirable. When a bank fails to meet the minimum HPM balance required, the Fed automatically books the 'fail' as a loan of reserves (much as 'overdraft' facilities routinely protect depositors of United Kingdom banks; American depositors can usually purchase overdraft insurance). In any case, a bank 'makes a loan', that is, purchases an asset, by 'creating a deposit', that is, shorting HPM.

As deposits are liabilities, banks do not worry about retaining them. However, when a check is written on a demand deposit, or when a maturing time deposit is not rolled-over, the bank is subject to a reserve, HPM, clearing drain. Since banks do not keep significant excess HPM balances, a clearing drain will cause a bank to fall below minimum HPM balance requirements. An individual bank will thus try to take a number of actions: 'purchase' HPM balances from the Fed, 'borrow' federal funds, 'sell' certificates of deposit, or 'repo' government bonds to meet minimum balance requirements. In the aggregate, the only 'net' source of HPM is the government, either the treasury or the central bank. When the treasury buys goods or services or provides transfer payments, it writes a check on the Fed, which ends up as a bank deposit of HPM at the Fed; when the Fed buys assets (government bonds, foreign currency, or commercial bank 
IOUs) it credits a bank deposit of HPM. In other words, any time when the treasury or central bank spends, HPM is created. On the other hand, tax payments work in reverse - destroy HPM as bank deposits at the Fed are debited. Furthermore, treasury or central bank sales of government bonds also drain HPM, thus reducing bank deposits at the Fed. The excess of government purchases over tax receipts (or 'deficit spending') generates an equivalent net injection of HPM.

All else equal, government deficit spending generates excess reserves (HPM deposits in excess of minimum balance requirements); bond sales by the government thus are required to offer an interest-earning alternative to non-interest-earning excess reserves. Over the very short run (for example, a day or two), the central bank ensures that the banking system as a whole has just the right amount of HPM to meet minimum balance requirements - mainly through open market sales and purchases of government bonds, although the discount window is also used - in order to maintain orderly overnight (federal funds) markets. In other words, regardless of its announced policy, the central bank always chooses a short-term (overnight) interest rate target and then ensures that the quantity of reserves is just sufficient to allow banks to meet minimum balance requirements. Over the longer run, it is primarily the treasury that supplies the right amount of bonds to drain excess reserves from the system. The treasury and central bank develop complex, coordinated operating procedures to ensure that the banking system is continuously supplied with the correct quantity of reserves (see Bell 1998 and Wray 1999).

Previous to the development of the federal funds market (created in the mid 1950s, but maturing in the early 1960s), individual banks used government bond sales or purchases to adjust HPM balances (Minsky 1957). A sale of a bond by a bank to a bond dealer would result in an HPM debit of the dealer's bank's reserves and a credit to the HPM reserves of the selling bank. Purchase of a bond would work in reverse - debit the bank's HPM reserves and lead to a credit of HPM to the bond dealer's bank. Thus, banks effectively used the bond dealers as 'middlemen' to shift bank reserves from those with excessive balances to those who were deficient. Apparently this is what has led to the widespread belief - in part shared by Minsky - that banks 'operated on assets', selling out bond positions in order to make loans.

With the development of the federal funds market, banks cut out the middlemen to market excess reserves, or HPM balances, directly. This transparency led many economists to believe that something of fundamental importance had changed - that banks had 'discovered' liability management, so that they would no longer need to sell bonds before making loans. While it is possible that many bankers may have believed 
themselves to be subject to reserve constraints such that they would, indeed, need to sell assets to obtain the reserves supposedly required to make loans, it is clear from balance sheet analysis that this was an imaginary constraint. Banks always 'operated on liabilities'. Rather than selling out positions in government bonds over the post-war boom, they instead 'leveraged' them.

From the perspective of the bank, loans to customers generate long positions in IOUs; similarly, its holdings of government bonds are long positions in securities. A bank is not forced to liquidate its long position in bonds to obtain a long position in customer IOUs. Rather, it simply needs to short HPM to go long in IOUs. There are many factors that may go into determining the willingness of a bank to take long positions in IOUs and short positions in HPM. Obviously, one of the most important factors is the existing differential between the interest rate it expects to earn on the IOUs and the rate it must pay to short HPM (equivalently, to get depositors to go long in 'bank money'). The bank, however, must also factor into the analysis other costs (minimum HPM balances that have to be maintained against some of its short positions; capital requirements against its long positions - which reduce the return on capital). More importantly, because the short positions commit the bank to deliver HPM in the future (for the most part, on uncertain dates), it must be concerned with the future terms on which HPM can be obtained. This is why the expected course of interest rates will be (perhaps imperfectly) reflected in today's quotes. A 'panic' or market break can occur when it is feared that HPM may not be obtainable on reasonable terms in the future - in which case banks won't go short to take long positions.

None of this should be interpreted to mean that the quantity of HPM acts as a constraint on banks' ability to lend. At the end, the Fed will supply exactly the quantity of reserves it requires banks to hold. The question is over the conditions that will be placed on obtaining HPM: what will be the cost of 'purchasing' HPM when reserves are needed, and what sorts of obstacles will the Fed impose on a bank to obtain them? A case in point is the credit crunch of 1966, which we analyze in the next section.

\section{Significance of the Credit Crunch of 1966}

Minsky argued that the Credit Crunch of 1966 was the first financial trauma since the 1930s that involved a run on a financial instrument or institution without a specific case of a failure or fraud (Minsky 1986, p. 87). Further, the financial crises that followed the 1966 crisis followed a similar pattern, with the crisis relieved by swift intervention by the 'Big Bank' Fed (plus a countercyclical 'Big Government' deficit in most cases).

According to Minsky, the long expansion of the 1960s progressed as 
spending by nonfinancial corporations grew rapidly, fueled in part by external funds provided by banks. As he showed, net external funds as a per cent of purchased physical assets grew from less than 4 per cent in 1961 to more than 20 per cent by 1966 (Minsky 1986, p. 88). Worried about inflation, the Fed began to raise interest rates. The discount rate was raised from 4 per cent to 4.5 per cent in December 1965 where it remained for the rest of 1966; the federal funds rate was also raised, but more rapidly throughout the year. In addition, the Fed raised reserve requirements on time deposits and lowered ceiling interest rates on small time deposits in July. The higher reserve requirements would effectively raise the cost of making loans (since reserves are a non-earning asset), while the lower ceiling rates would force banks to turn to higher-cost, nonregulated sources of funds (by inducing 'disintermediation' - as we discuss below). Finally, after April the Fed directed that reserve growth should be restricted and tried to discourage discount window borrowing; Minsky reports that by July and August, the 'window was so tightly administered that there was no increase in borrowing by member banks, and the moneymarket banks believed that the discount window was effectively closed to them' (Minsky 1986, p. 90). In sum, monetary policy was tightened significantly on the belief that banks could be pressured to reduce lending that was fueling the expansion.

When the Fed began to raise interest rates in 1966, market rates were quickly pushed above Regulation Q ceilings (maximum interest rates permitted on deposits). Market savvy 'depositors' liquidated their long positions in regulated deposits and searched for better returns. This hurt the large New York banks relatively more than it would hurt the mid-western thrifts that relied on small share accounts of mom-and-pop depositors. Deposits tended to 'flow out' of New York banks and into 'Eurodollar' accounts of foreign banks, or, more simply, into accounts of foreign branches of US banks. Eurodollar deposits were not covered by Regulation Q (thus, raised costs) but did not require minimum HPM balance requirements (legally required reserves) until 1969 (which offset some of the increased cost). In addition, banks innovated to provide Americans with deposit accounts that circumvented Regulation Q (negotiable order of withdrawal (NOW) accounts) but these, too, promised higher interest rates - especially in comparison with zero-interest-earning checking accounts.

Not only were costs higher, but there was no way to know how high the Fed would raise interest rates, and there was every indication that the Fed would impose more obstacles for the banks to overcome. Fiscal policy remained expansive and the administration's success at informal wage and price controls was, at best, questionable. As a result, it was reasonable for 
'the market' to conclude that monetary policy, alone, would be responsible for fighting inflation and that meant that interest rates could rise sharply. In such an expectational environment, banks were reluctant to 'short' HPM to go long in IOUs and securities. Some banks might even have tried to liquidate long positions in securities to continue to service valued customers (providing additional loans) without increasing short positions. However, while sales of bonds by an individual bank could increase its own deposits of HPM, this could not increase system-wide HPM deposits unless the sales were to the Fed.

Under Regulation Q, tight money episodes tended to reduce bank willingness to buy bonds as occurred in 1957, 1960, 1966 and 1969 when the federal funds rate spiked, and in every case bank holdings of US government securities fell sharply. This probably has more to do with the uncertainty generated by tight policy over the terms on which HPM can be obtained, as well as with the unexpected capital losses that might accrue to bonds if the Fed should persist in raising interest rates. Thus, while banks do not have to sell bonds to make loans, during tight money periods they choose not to increase bond holdings, and, indeed, in such periods reduce bond holdings by several billion dollars. In 1966, this led to a disorganized municipal market that forced the Fed to intervene.

Minsky argued that the US economy emerged from World War II with a 'robust' financial system with a predominance of 'hedge' financing. Bank balance sheets were flush with US government securities - about 40 per cent of total banking credit in 1955. This was a consequence of conservative financial practices (due in part to supervision and regulation, but also to memories of the Great Depression and to 'evolutionary' forces that had eliminated risk-lovers during the 1930s), of the tremendous government deficits of World War II (and the consequent issue of government bonds), and of the lack of opportunity to lend to the private sector (due to war-time controls, temporary nationalization of industry, and large household savings). Gradually, as the private sector began to grow and as memories of the Great Crash faded, balance sheet leveraging increased. Nonfinancial firms increased borrowing, committing larger portions of expected income flows to debt service; financial firms, including banks, financed this activity by increasing the ratio of loans (and other riskier assets) to government securities. The major change to the composition of bank credit was the rapid, sustained decrease of the importance of US government securities and the similarly rapid and sustained increase of the importance of loans. US government securities fell to less than a fifth of bank credit by 1966; in contrast, bank loans (excluding mortgages and consumer credit) rose rapidly from 24 per cent of bank credit in 1955 to 33 per cent by 1966. Financial innovations allowed banks to increase HPM 
leverage ratios - that is, to issue more liabilities without increasing reserve requirements.

Furthermore, banks, especially, moved from reliance on relatively stable demand deposits (which, while payable on demand are actually quite predictable) to greater reliance on time deposits (which, except for passbook savings accounts, are unstable) - as Minsky shows, demand deposits made up approximately 70 per cent of total bank liabilities in 1952, but this had already fallen to about 40 per cent by 1966 . As discussed, fear of inflation led the Fed to increase interest rates over the course of the expansion; the federal funds rate rose from less than 2 per cent in 1961 to 5.75 per cent in 1966, causing market rates to rise sharply (the six month certificate of deposit (CD) rate peaked at nearly 6.15 per cent in mid 1966). While banks can always eventually adjust to higher rates, rising rates reduce profitability because assets are generally longer-term than liabilities. This is particularly true of thrifts - whose problem in 1966 was not so much that Regulation Q limited the interest rate they could pay on deposits but rather that they could not 'afford' to pay market rates given their return on mortgage assets. Similarly, as noted above, the problem faced by commercial banks was not 'disintermediation' but rising costs of issuing liabilities and uncertainty regarding the future course of interest rates. Finally, while banks could continue to provide loans to their customers, the loans required higher interest rates and thus required that borrowers would devote ever-higher portions of expected income flows to debt service. Given all these factors, but especially uncertainty over exactly how high the Fed would push interest rates, banks reduced their demand for government bonds - including US treasuries as well as municipal bonds. Between the fourth quarter of 1965 and the third quarter of 1966, banks sold $\$ 6$ billion of US government securities, in addition to the $\$ 440$ million municipal securities sold between the third and fourth quarters of 1966. Banks also sold off $\$ 340$ million of corporate and foreign bonds between mid 1965 and midyear 1966. By late August, the large New York banks had withdrawn altogether from the municipal new issues market (Minsky 1986, p. 89).

As Minsky argues ' $[\mathrm{b}] \mathrm{y}$ the end of August, the disorganization in the municipals market, rumors about the solvency and liquidity of savings institutions, and the frantic position-making efforts by money-market banks generated what can be characterized as a controlled panic. The situation clearly called for Federal Reserve action' (Minsky 1986, p. 90). There is no doubt that the Fed was concerned about a potential mass bank withdrawal from the municipal market. As Minsky (1986) and Wolfson (1994) note, the Fed sent a letter on September 1 to all member banks emphasizing that '[f]urther substantial adjustment through bank 
liquidation of municipal securities or other investments would add to pressures on financial markets' (quoted in Wolfson 1994, p. 38). Effectively, the Fed announced it would open the discount window to all banks that would continue to hold municipal bonds so long as they could show they were constraining business lending.

What we have, then, is a robust post-war expansion during which liquidity is stretched. Fearing inflation, the Fed tightens monetary policy to the point at which profitability of at least some financial institutions is threatened. Growing uncertainty causes a run out of a portion of the securities market. The Fed enters as lender of last resort to stop the run, and within a few months, it is forced to loosen monetary policy. The financial crisis is quickly relieved, although the conditions placed on the lender of last resort intervention (that borrowing banks must show they are attempting to reduce loans to private business) cause a sharp reduction of investment, 'gross private domestic investment decreased at an annual rate of 26 percent between the fourth quarter of 1966 and the second quarter of 1967' (Minsky 1986, p. 90). This was accompanied by a large decline of the rate of growth of bank credit, which had been growing at about 8 per cent per year from December 1965 through July 1966, but the rate of growth fell to 1.5 per cent per year between July and December 1966 (Minsky 1966, p. 89).

However, a recession did not result because government spending more than compensated for the fall of investment; 'Big Government' maintained aggregate demand. Thus, as Minsky always argued, the two most important roles for government ('Big Bank' intervention as lender of last resort, and 'Big Government' spending to provide a floor to aggregate demand) came into play to stop the 1966 'crunch' from generating a recession. The economy continued to expand, new financial practices emerged and were validated, leverage ratios increased, memories of the Great Depression faded, and markets came to expect that big government and the Fed would come to the rescue as needed. The 1966 credit crunch was followed by extremely tight money policy at the end of the 1960s, then by the 'liquidity squeeze' and commercial paper run of 1970, the bank failures of 1973-75, the silver crisis of 1980, the LDC debt crisis of 1982, the saving and loan fiasco of the mid-1980s (and similar banking problems throughout the world), the 1987 stock market crash, the bond market crash of 1994, the Asian meltdown of 1997-99, the stock market crash of 2000, the Russian default and hedge fund crisis of 1998, and the Great Recession of 2007-09. That 1966 crisis was only a minor speed bump on the road to Minskyan fragility, but in broad outline the central features and policy responses were similar in the crises to come later.

In the next section we examine Volcker's Great Monetarist Experiment 
and its long-term impact on the financial sector, which set the stage for the current crisis.

\section{Monetarism, the rise of securitization, and the demise of commercial banking}

After the Fed-Treasury Accord (1951), the Fed was 'freed' to use interest rate hikes to try to fight inflation and eventually to fine-tune the economy (Wray 2008). Over time, its interventions became increasingly aggressive - finally culminating in the Great Monetarist Experiment of 1979-82, during which Fed Chairman Volcker raised the overnight rate above 20 per cent. While interest rates were never pushed up so high again, the Fed continued with aggressive attempts at fine-tuning all the way to the present crisis. Indeed, it began to practice 'preemptive' interventions, arguing that due to lags between the time action was taken and impacts on inflation, it needed to fight inflation even before it appeared. This forced financial institutions to speed the transformation away from relationship banking and toward a 'market-based' approach.

Previously to the time of the Monetarist experiment, each rate hike to fight inflation caused problems for commercial banks and thrifts that were subject to Regulation Q interest rate ceilings, as well as usury laws that limited loan rates, causing them to suffer retail deposit withdrawals when market rates rose above legislated deposit rates. To retain reserves they had to substitute more costly wholesale deposits not subject to Regulation Q. At the same time, they had to raise interest rates on loans, causing their best customers to turn to other sources of funds, such as commercial paper markets. Thus the interest rate ceilings allowed the Fed to engineer 'credit crunches' by pushing market rates up. In addition, other rules and regulations that dated to the New Deal financial reforms also constrained bank practices to preserve safety and soundness.

However, as Minsky argued, financial institutions responded to each tight money episode by innovating, creating new practices and instruments - making the supply of credit ever more elastic. The development of secondary markets in mortgages as well as the creation of 'hot money' jumbo certificates of deposit in the 1980s were financial innovations directly responding to the high interest rate monetarist experiment used by Volcker to fight stagflation (Wray 1994). As time passed, the increasing tendency toward speculative booms became correspondingly more difficult to contain. Furthermore, the Fed and Congress gradually removed constraints; ultimately the Glass-Steagall Act that had separated commercial and investment banking was repealed in 1999, allowing commercial banks to engage in a wider range of practices so that they could better compete with their relatively unregulated Wall Street competitors. As Minsky 
argued, at each step, innovation and deregulation allowed increasingly risky practices to make the system more vulnerable.

Still, deregulation and legal recognition of new practices were not, by themselves, sufficient to bring on a global financial crisis. If these innovations had led to excessively risky behavior that generated huge losses, financial institutions would have been reluctant to retain them. According to Minsky, the remarkable thing about the post-war period is the absence of depressions. While recessions occur with regularity, they are constrained; while financial crises arise from time-to-time, the fall-out is also contained. This is due in part to the various reforms that date to the New Deal, but also to countercyclical movement of the 'Big Government' budget, to lender of last resort activity of the 'Big Bank' Fed, and to periodic bail-outs arranged by the Fed, Treasury, or Congress. As Minsky always argued, by preventing 'It' (a debt deflation on the order of the 1930s collapse) from happening again, new practices and instruments were validated.

In other words, the upside exuberance observed in each bubble is just the end result of long-term policy-induced, and in turn policy-validated, profit-seeking financial innovations that stretched liquidity and enabled prices of real estate, of equity, and of commodities to reach unjustified and unsustainable levels. Just as what was termed by Chairman Greenspan the irrational exuberance that developed in equity markets in the 1990s was based on the belief that a 'new economy' had created conditions in which dotcoms could only rise in value - validating exploding stock prices - the 2000s saw unprecedented real estate appreciation that validated increasingly Ponzi finance. Yet both bubbles were fueled by a combination of optimistic expectations developed over many years and the search for high returns by money fund managers of accumulated wealth over decades. In the case of the real estate boom, the argument was that real estate prices 'always go up', and, having entered the era of the 'great moderation' competent central bankers were firmly in control of the economy, so that there were few downside risks.

Over this period, growth of what Minsky called managed money competed with traditional bank lines of business, as pension funds, insurance funds, hedge funds, and so on, provided an alternative source of funds in competition with bank loans. Initially, bank funding had an advantage over market sources of funding because banks could diversify risks across a large number of borrowers with different income sources. Further, banks had access to insured deposits as well as to Fed lender of last resort intervention, ensuring they could issue liabilities without facing much chance of a run. However, by the early 1970s, firms were already turning in large numbers to the commercial paper market for short-term borrowing. As 
Minsky (1986) noted, an early 1970s crisis in the commercial paper market led to the practice of obtaining back-up lines of credit with banks. On one hand, banks then could earn fee income for provision of the back-up facilities, but on the other, this practice reduced their competitive advantage in direct funding of business. Another market innovation allowed for diversification of risk by issuing securities collateralized by pooling loans detailed below. Taken together, such innovations reduced the advantages banks had previously held.

Over time, new instruments continually eroded the bank share of assets and liabilities - which fell by half between the 1950s and the 1990s: the securities market share of private nonfinancial debt rose from 27 per cent in 1980 to 55 per cent in 2008 (Greenlaw et al. 2008). Banks were forced to become more market-oriented. They would settle for a smaller share of the financial system, and servicing Wall Street firms would replace some of the relationship banking they had lost. Minsky (1987) observed that banks appear to require a spread of about 450 basis points between interest rates earned on assets less that paid on liabilities. This spread covers the normal rate of return on capital, plus the required reserve 'tax' imposed on banks (reserves are non-earning assets), and the costs of servicing customers. By contrast, financial markets can operate with much lower spreads precisely because they are exempt from required reserve ratios, regulated capital requirements, and much of the costs of relationship banking.

Banks had to find a way to economize. To restore profitability, they would earn fee income for loan origination, but by moving loans such as mortgages off their books they could escape reserve and capital requirements. They could, however, continue to service the loans, earning additional fees. Investment banks would purchase and pool these loans, then sell them as securities to investors. As Minsky (1987) argued, investment banks would pay ratings agencies to bless the securities, and hire economists to develop models demonstrating that interest earnings would more than compensate for the assumed risks. Risk raters and economic modelers would certify that prospective defaults on the underlying assets would be low enough to justify the investment-grade rating required by insurance and pension funds. All told, these developments appeared to offer an alternative to relationship banking. There was no need to develop relationships with individual borrowers to assess credit worthiness because loan pools diversified risks, raters evaluated the risks of the overall pools, and insurers protected against possible losses. To replace lost income, banks began to take direct positions in the poolers, the securities, and the insurers. They also provided back-up liquidity guarantees to those involved in packaging and selling securities, and even gave money-back guarantees to holders of 
securities if the underlying loans went bad. Ironically, this meant that they were now exposed to default risk of borrowers they had never assessed. And, as it turned out, no one had assessed those risks.

\section{Securitization and the current global collapse}

Securitization is a 'market-oriented' financial practice in contrast to 'bank-based' transactions where activities are financed by loans held on bank balance sheets against deposits held in the banking system. Securitization has also been called the 'originate and distribute' model, which accurately captures a distinguishing feature of the process: the institution that arranges the finance of activities does not hold the loan. Lots of presumptions about these instruments and practices have been exploded by the crisis, including the belief that securitization shifted risks off bank balance sheets, that securitization allowed for diversification of risks while efficiently allowing investors to achieve the proper risk-return trade-off, and that securitization put risk into the portfolios of those best able to handle it.

Minsky (1987) argued that securitization was part and parcel of the globalization of finance, as securitization creates financial paper that is freed from national boundaries. German investors with no direct access to America's homeowners could buy a piece of the action in US real estate markets. As Minsky was fond of pointing out, the unparalleled postWorld War II depression-free expansion in the developed world (and even in much of the developing world) has created a global sea of managed money seeking returns. Packaged securities with risk weightings assigned by respected credit rating agencies were appealing for global investors trying to achieve the desired proportion of dollar-denominated assets. It would be no surprise to Minsky to find that the value of securitized American mortgages exceeded by a large margin the value of the global market for federal government debt.

The problem is that the incentive structure in which mortgage originators operated was certain to create problems. In the aftermath of the 2000 equity market crash, investors looked for alternative sources of profits. Low interest rate policy by the Greenspan Fed meant that traditional money markets could not offer adequate returns. Investors lusted for higher risks, and mortgage originators offered sub-primes and other 'affordability products' with ever-lower underwriting standards. Brokers were richly rewarded for inducing borrowers to accept unfavorable terms, which increased the value of the securities. New and risky types of mortgages - hybrid adjustable rate mortgages (ARMs) (called ' $2 / 28$ ' and ' $3 / 27$ ') that offered low teaser rates for two or three years, with very high reset rates - were pushed, even by Fed Chairman Greenspan. 
While the troubled instruments and institutions varied, many of today's problems can be traced back to securitization. While seemingly innocuous, securitization led to a dizzying array of extremely complex instruments that - quite literally - no one understands. Throughout the financial world, 'mark to model' or even 'mark to myth' substituted for 'mark to market' because markets could not value the instruments. The current financial crisis began in the market for mortgage-backed securities (MBS), especially in the sub-prime section of that market. It quickly spread to securities backed by 'Alt A' mortgages (less risky than sub-prime, but too risky to qualify for conventional loans), and then to more exotic markets including collateralized debt obligations (CDOs), asset-backed commercial paper (ABCP), and other asset-backed securities (ABS), including other types of consumer debt. Furthermore, problems spread beyond specific asset classes to institutions such as special purpose vehicles (SPVs), including structured investment vehicles (SIVs) - monoline insurers (that provide insurance for MBS), and to major financial institutions (including private banks as well as government sponsored enterprises like Fannie Mae). Still other financial instruments faced problems, such as municipal bonds and credit default swaps (CDS). Finally, the credibility of real estate agents, property appraisers, accountants, credit rating agencies, mortgage brokers, and financial institution officers was called into question because of practices developed over the decade preceding the collapse.

Thus, by 2007 we faced a systemic problem resulting from the notion that markets can properly assess risk based on complex, backwardlooking models; that markets can hedge and shift risk to those best able to bear it; and that market forces will discipline decision-making. Alas, each of these presumptions proved to be woefully incorrect. The models were constructed based on data generated during an unusually stable period in which losses were small, and required that the structure of the financial system remain constant. But as Minsky (1986) argued, relative stability will necessarily encourage behavior that changes the financial structure (he used the terms hedge, speculative, and Ponzi to describe the transformation). This evolution, in turn, rendered the models increasingly useless even as they were used on a grander scale to justify falling interest rate spreads implying virtually no defaults would ever occur. Further, as is now recognized, the models could not account for growing interrelations among debtors increasing the systemic risk that insolvency by some would generate a snowball of defaults. This was another process that Minsky always emphasized, and one that is enhanced by the kind of leveraging that became common as margins of safety were reduced. Further, as we now know, neither was risk properly hedged nor was it necessarily shifted. 
Much of it came back directly to banks through buy-back guarantees, back-up credit facilities, and bank purchases of securities.

Finally, markets did not discipline behavior but instead encouraged ever-riskier activities. For example, the increased competition coming from managed money narrowed interest rate spreads but because fund managers were in a desperate search for high returns they were forced to ignore risk where it was under-priced. Competition forced them to take excessive risk given returns. Many did not even pretend to understand the instruments they were buying, as they were content to either rely on credit rating agencies or to simply follow the leader down the inevitable path to destruction.

\section{Where do we go from here? A Minskyan transformation of the financial system}

Let us begin with four appropriate quotes from Minsky (1987) (with a few of our editorial comments in square brackets; original italics):

Securitization throws light on the nature of money: money is a financial instrument (debt) that develops out of the financing of activity and positions in assets and becomes generally accepted in an economic community as a means of payment for goods and services and as an instrument by which debts are discharged.

It is conceivable that in the not too distant future we could be using $\$ 100$ interest bearing short-term securities as currency. Private money is a distinct possible future outcome of current developments.

Securitization implies that there is no limit to bank initiative in creating credits for there is no recourse to bank capital, and because the credits do not absorb high-powered money [bank reserves]. Both capital and reserve absorption may occur at the initiating stage of the credit [before the securities can be created and sold]. This has led to the terminology of 'bridge financing.' [But once the securities are moved off the bank balance sheet, neither capital nor reserves are leveraged any longer.]

Securitization lowers the weight of that part of the financing structure that the central bank (Federal Reserve in the United States) is committed to protect. A need by holders of securities who are committed to protect the market value of their assets (such as mutual or money market funds, or trustees for pension funds) may mean that a rise in interest rates will lead to a need by holders to make position by selling position, which can lead to a drastic fall in the price of the securities.

These statements, written in 1987, not only provide a concise summary of Minsky's views on money and finance but also a prescient overview of the evolution of financing that occurred over the next two decades as well as hints of the form the crisis would take. Let us return to his statement 
that 'anyone can create money' - a financial instrument that develops out of the financing of activity or asset purchases. Mortgage-backed securities were the instrument that financed the real estate boom; positions in these securities were taken through the issue of shorter-term IOUs such as commercial paper. As Minsky recognized, because banks quickly moved mortgages off their balance sheets, most of this activity absorbed neither reserves nor capital - this was an innovation capable of creating an infinite supply of finance, to support an infinite run-up of real estate prices. Of course, this could not go on forever - because at some point, real estate prices must be validated by the ability of the mortgagee to service debt. And, as mentioned earlier, any number of events might have triggered the crisis. Because the 'shadow banks' and their instruments were formally outside the protection of the Fed and Treasury, insolvency problems quickly led to a liquidity crisis. After some false steps, both Big Government and the Big Bank came to the rescue of the shadow banks with a huge array of bail-outs, guarantees, arranged mergers, and loans. In addition, the few remaining investment banks were handed bank charters so they would have access to insured deposits as well as to the lender of last resort. In this manner, the liquidity crisis greatly expanded the protection and role of both branches of government. The result is an untenable socialization of risks to protect private profits. At the same time, economic power has been concentrated in a handful of hegemonic financial institutions that are already as we write resuming many of the practices that brought on the crisis.

\section{What would Minsky suggest?}

First let us address what kinds of financial services must be provided; then we turn to the reconstitution of the financial system to ensure these are provided but within the context of a more stable system.

Among the kinds of services that must be provided, Minsky listed the following:

1. Payments system: deposit banking, postal savings, debit cards

2. Secure outlet for savings: narrow banks, insured deposit accounts, postal savings

3. Finance for housing and consumers: mortgages, credit cards, consumer loans

4. Commercial banking services: commercial loans, credit cards, payments services, deposit accounts, business savings

5. Investment banking services: equity issues, take-out finance

6. Asset management advice and accounts: retail stock brokers

7. And to his list we add Insurance: home, auto, life, health, business 
The New Deal provided functional separation, but that was gradually eroded and then eliminated with the repeal of the Glass-Steagall Act. Yet it is not clear that 'universal banking' has been a success. Minsky actually did advocate a form of universal banking, but only for small community development banks. These would have been for-profit but closely regulated and publicly subsidized so that they would operate in the public purpose. The goal was to use them to provide needed financial services to underserved low-income citizens, inner-city minorities, and entrepreneurs who seek modest financing for small businesses. The community development banks proposal was unique since it emphasized the need for the development of an equitable payments system for the bottom quintile of the population, which is generally denied access to checking accounts and other services (Minsky et al. 1992 [1996]). These institutions were neither to be viewed as a significant countercyclical force, nor as a major factor in the growth of the economy, but rather designed to fill a gap in the ongoing institutional structure. Further, they could very well provide part of the institutional setting in which a climate of opportunity replaced stagnation for many segments of the population.

The problem of the existing system and the consequent recent crisis is systemic and derived from a fundamentally flawed model that viewed the move to markets as something that would increase efficiency and lower interest rate spreads while spreading and reducing risk. This was accomplished by reducing reliance on relationship banking and letting markets take over much of the financial sector. Yet, as Minsky always argued, the fundamental banking activity is guaranteeing credit worthiness. This requires a skeptical loan officer who carefully evaluates borrowers, and who reduces probability of default by establishing a long-term relationship such that credit is renewable only if the borrower fulfills obligations. The shift to the market 'originate and distribute' model meant that individual creditworthiness was never assessed. However, banks guaranteed creditworthiness, anyway, through a wide variety of exceedingly complex and mostly hidden agreements with originators and holders of securities.

So the key to restoration of healthy banking is to recognize, as Minsky did, that banking is a profit-seeking business based on very high leverage ratios. Banks, also, serve an important public purpose and thus are rewarded with access to the Fed's lender of last resort function and to government guarantees. What this means is that as soon as capital ratios decline toward some minimum (zero in the case of an institution subject only to market discipline, or some positive number set by government supervisors as the point at which they take over the institution), management will 'bet the bank' by seeking the maximum, risky, return permitted by supervisors. In any event, there is always an incentive to increase 
leverage ratios to improve return on equity as Minsky (1986) showed. Given that banks can finance their positions in earning assets by issuing government-guaranteed liabilities, at a capital ratio of 5 per cent for every $\$ 100$ they gamble, only $\$ 5$ is their own and $\$ 95$ is the government's. If subjected only to market forces, profit-seeking behavior would be subject to many, and frequently spectacular, bank failures. The odds are even more in their favor, if government adopts a 'too big to fail' strategy - although exactly how government chooses to rescue institutions will determine the value of that 'put' option to the bank's owners.

Given these considerations there are three alternative but complementary strategies for dealing with banks: (a) require very high capital ratios; (b) require very safe assets; or (c) provide restrictive regulations and close supervision. Considering the first strategy, at the extreme, a 100 per cent capital requirement would ensure that the bank's owners would suffer all of the loss (and receive all of the gain) incurred on assets. In theory, that is the idea behind Islamic Banking. Jimmy Stewart's thrifts that operated as mutuals were similar - the deposits were really shares, and interest paid out was a distribution of the earnings. These worked exceedingly well for a very long time, but as described above they required an implicit assurance that the Fed would not use aggressive interest rate hikes. Of course, there was also a guarantee on the value of deposits and close regulation of the types of assets that could be held. The combination of high interest rates plus relaxation of regulation (including ownership rules) devastated the thrifts. However, a number of different models based on the mutual form of ownership as well as a large increase of capital ratios might generate new financial institutions that could provide a variety of financial services.

Note that while the Basel agreements were supposed to increase capital requirements, the ratios were never high enough to make a real difference, and financial institutions were allowed to assess the riskiness of their assets for the purposes of calculating risk-adjusted capital ratios. In reality, the Basel agreements contributed to the financial fragility that resulted in the global collapse of the financial system. Effective capital requirements would have to be very much higher, and if they are risk-adjusted, the risk assessment must be done at arms-length by unaffiliated parties. We conclude that short of a return to the mutual form, or imposition of very high capital requirements, additional constraints will be required.

Taking the second strategy, an extreme would be ' 100 per cent money' institutions with access to government guarantees could hold only federal government liabilities (reserves plus bonds). Minsky endorsed such a proposal put forward by Ronnie Phillips (1995). To ensure competitive space for such institutions, government would have to remove guarantees (including the implicit but vaguely defined 'too big to fail' guarantee) from 
other types of financial institutions. Obviously, this would be moving in the opposite direction to the decisions taken during this crisis to hand bank charters to investment banks such as Goldman Sachs, which extended access to the 'government's money' (insured deposits) to the riskiest activities. Thus, separation of financial institutions into a 100 per cent money segment and an unprotected segment would be radical and politically difficult. Further, it is not clear that the temptation to provide 'emergency' guarantees in a crisis to the unprotected sector could be avoided. The socalled 'systemically important' institutions would therefore benefit from a presumed government guarantee in 'normal' times, making it difficult for the 100 per cent money sector to compete for deposits.

For this reason it seems that the best course of action would be the third strategy of creating new rules and regulations, and strengthening supervision. Both are necessary because as bank chief executive officers (CEOs) as well as government supervisors have publicly recognized, the financial instruments and practices developed over the past decade are far too complex to understand, let alone to supervise. Regulations will need to prevent some classes of financial institutions from using financial instruments and practices - many of which have already failed a 'market test' - deemed too complex. Supervision is required, because it is impossible to write rules and regulations to cover innovations yet to be developed. For this reason, both supervision as well as regulation is required. Some have advocated an FDA-type approach - financial instruments and practices are prohibited until they have been specifically approved by regulators.

Policy should avoid promotion of financial institution consolidation - a natural result of financial crises that can be boosted by policy-arranged bailouts. Minsky always preferred policy that would promote small-tomedium sized financial institutions. Unfortunately, policymakers who are biased toward 'free markets' instinctively prefer to use public money to subsidize private institution takeovers of failing financial firms. President Roosevelt's alternative should be adopted: temporary 'nationalization' of failing institutions with a view to eventually return them to the private sector at a small profit to the US Treasury. This is what Minsky advocated during the thrift crisis of the 1980s, but the administration of the first President Bush chose industry consolidation and public assumption of bad assets that resulted in Treasury losses. Policy should instead foster competition, with a bias against consolidation. And, following Minsky, it should return to a bias toward market segmentation, with greater regulation of the banking, protected, sector. Minsky always advocated smaller financial institutions, but halting the trend to bigness will be difficult (Minsky 1986). Unless the largest institutions can be down sized it is difficult to believe that government regulators and supervisors will be successful: 
large institutions capture regulators but more importantly they can buy political influence to intervene on their behalf (the Keating Five comes to mind). And, as mentioned above, those institutions that escape regulation and supervision (for example, because they are not classified as 'banks') still might enjoy the perception that they will be protected in the case of crisis - another reason for the bias against 'too big to fail' institutions. In an important sense, any institution that is too big to fail is probably too big to exist as a private for-profit institution; indeed it should probably be operated as a public institution (a government sponsored enterprise).

The 'originate and distribute' model has shown its weakness and is unlikely to survive in its present form. Risk raters, property appraisers, quant models, and broker's markets cannot substitute for relationship banking. Managers of money funds that are too big to fail must be constrained because they will again get caught up in the next financial fad. Market forces induce each to try to beat the market, but that requires ignoring greater risk to obtain the higher returns.

To be sure, there is nothing to be gained by preventing everyone from taking on excessive risk. However, there is a clear public interest in the management of pension and insurance funds, which is supposed to be biased toward safety and soundness. Hedge funds and private equity funds are a different matter, but even these need supervision and regulation because of the potential impacts they can have on the economy - as Long-Term Capital Management (LTCM), Enron, and other examples have demonstrated.

\section{Conclusion: what we learned from Minsky}

Minsky argued that the Great Depression represented a failure of the small-government, laissez-faire economic model, while the New Deal promoted a 'Big Government/Big Bank' highly successful model for financial capitalism. The current crisis just as convincingly represents a failure of the 'Big Government'/Neoconservative model that promotes deregulation, reduced supervision and oversight, privatization, and consolidation of market power in the hands of money manager capitalists. In the US, there has been a long run trend that favors 'markets' over 'banks', that has also played into the hands of neoconservatives. The current financial crisis is a prime example of the damage that can be done.

The New Deal reforms transformed housing finance into a very safe, protected, business based on (mostly) small, local financial institutions that knew their markets and their borrowers. Homeownership was promoted through long term, fixed rate, self-amortizing mortgages. Communities benefited, and households built wealth that provided a path toward middle class lifestyles (including college education for baby-boomers and 
secure retirement for their parents). This required oversight by regulators, Federal Deposit Insurance Corporation (FDIC) and Federal Savings and Loan Insurance Corporation (FSLIC) deposit insurance, and a commitment to relatively stable interest rates. Other policies identified by Minsky as 'paternalistic capitalism' also helped to build a robust economy: cooperation with unions to ensure rising wages and thus growing consumer demand; a social safety net that also encouraged consumption; student loans that enhanced earnings capacity; and a sense of shared responsibility to take care of the young, the old, and people with disabilities. Together, these policies reduced insecurity, enhanced trust, and promoted economic stability.

Over time, however, the economy gradually evolved toward fragility. The cold war favored investment in the leading industries, where wages were already high. Inequality grew as other sectors and workers with less education fell behind. Social programs were cut and trickle-down economics favored growth of inequality. Policy increasingly turned to promotion of investment in particular, and business in general, to fuel growth - rather than relying on growing consumption financed out of growing household incomes. Because a large portion of investment in our type of economy must be externally financed, this policy mix increased the importance of finance. At the same time, absence of a depression in the post-war period allowed financial wealth to accumulate, albeit increasingly in the hands of an elite. A formally 'anti-government' bias led to the erosion of many of the New Deal reforms. In practice, however, the rising conservative ideology never really embraced a return to the pre-war small government form of capitalism, but rather merely substituted a meaner big government for the paternalistic government of the early post-war period. Hence, the 'Big Government'/Neoconservative model replaced the New Deal reforms with self-supervision of markets, with greater reliance on 'personal responsibility' as safety nets were dismantled, and with monetary and fiscal policy that is biased against maintenance of full employment and adequate growth to generate rising living standards for most Americans. In short, the government was neither smaller nor less interventionist. The constituency had, however, changed away from America's middle class and toward Wall Street's money managers. We turned American home finance over to Wall Street, which operated the industry as if it were a casino.

Minsky insisted that 'the creation of new economic institutions which constrain the impact of uncertainty is necessary', arguing that the 'aim of policy is to assure that the economic prerequisites for sustaining the civilized standards of an open liberal society exist. If amplified uncertainty, extreme income maldistribution and social inequalities attenuate the economic underpinnings of democracy, then the market behavior that 
creates these conditions has to be constrained' (Minsky 1996, pp. 14, 15). It is time to take home finance back from the hands of Wall Street's casino operators.

We believe that the chapters in this book contribute to an understanding of the reformation that will be required, following the insights developed by Minsky over the first half-century of the post-war period. We hope that the growing recognition of the importance of Minsky's contributions will finally bring to the greatest 'financial Keynesian' the accolades he deserves.

\section{References}

Bell, S. (1998), 'Can taxes and bonds finance government spending?', Working Paper No. 244, Levy Economics Institute of Bard College, Annandale-on-Hudson, New York.

Bellofiore, R. (1985), 'Money and development in Schumpeter', Review of Radical Political Economics, 1-2, 21-40.

Bellofiore, R. (1992), 'Monetary macroeconomics before the General Theory. The circuit theory of money in Wicksell, Schumpeter and Keynes', Social Concept, 2, 47-89.

Ferri, P. (1992), 'From business cyles to the economics of instability', in S. Fazzari and D.B. Papadimitriou (eds), Financial Conditions and Macroeconomic Performance: Essays in Honor of Hyman P. Minsky, Armonk, NY: M.E. Sharpe, pp. 105-20.

Godley, W., D.B. Papadimitriou and G. Zezza (2006), 'America and her creditors: thinking the unthinkable', Milken Institute Review, Second Quarter.

Greenlaw, D., J. Hatzius, A. Kashyap and H.S. Shin (2008), 'Leveraged losses: lessons from the mortgage market meltdown', paper presented at the US Monetary Policy Forum Conference (February 29).

Minsky, H.P. (1957), 'Central banking and money market changes', Quarterly Journal of Economics, 71 (May), 171-87.

Minsky, H.P. (1964), 'Longer waves in financial relations: financial factors in the more severe depressions', American Economic Association Papers and Proceedings, 54 (May), 324-32.

Minsky, H.P. (1966), 'Tight full employment: let's heat up the economy', in H.P. Miller (ed.), Poverty American Style, Belmont, CA: Wadsworth Publishing Co., pp. 254-300.

Minsky, H.P. (1975 [2008]), John Maynard Keynes, New York: Columbia University Press, republished in D.B. Papadimitriou and L.R. Wray (eds), Hyman P. Minsky's John Maynard Keynes, New York, NY: McGraw-Hill.

Minsky, H.P. (1986 [2008]), Stabilizing an Unstable Economy, New Haven, CT.: Yale University Press, republished in D.B. Papadimitriou and L.R. Wray (eds), Hyman P. Minsky's Stabilizing an Unstable Economy, New York, NY: McGraw-Hill.

Minsky, H.P. (1987), 'Securitization,' Handout, Econ 335A, Fall, mimeo, Archives, Levy Economics Institute of Bard College, Annandale-on-Hudson, New York.

Minsky, H.P. (1992), 'Profits, deficits and instability: a policy discussion', in D.B. Papadimitriou (ed.), Profits Deficits and Instability, New York, NY: Macmillan and St. Martin's Press.

Minsky, H.P. (1996), 'Uncertainty and the institutional structure of capitalist economies', Working Paper No. 155, Levy Economics Institute of Bard College, Annandale-onHudson, New York.

Minsky, H.P., D.B. Papadimitriou, R.J. Phillips and L.R. Wray (1992 [1996]), 'Community development banks', Working Paper No. 83, Levy Economics Institute of Bard College, Annandale-on-Hudson, New York; republished in D.B. Papadimitriou (ed.) (1996), Stability in the Financial System, New York, NY: Macmillan and St. Martin's Press.

Phillips, R.J. (1995), The Chicago Plan and New Deal Banking Reform, Armonk, NY: M.E. Sharpe, Inc. 
Schumpeter, J.A. (1944), 'The analysis of economic change', in Readings in Business Cycle Theory, The AEA, Philadelphia: The Blakiston Co.

Schumpeter, J.A. (1934 [1949]), The Theory of Economic Development: An Inquiry into Profits, Capital, Credit, Interest, and the Business Cycle, Cambridge, MA: Harvard University Press.

Schumpeter, J.A. (1951), 'The creative response in economic history', in R.V. Clemence (ed.), Essays on Economic Topics of J.A. Schumpeter, Port Washington, NY: Kenikat Press.

Wolfson, M.H. (1994), Financial Crises: Understanding the Postwar U.S. Experience, second edition, Armonk, NY: M.E. Sharpe.

Wray, L.R. (1994), 'The political economy of the current US financial crisis,' International Papers in Political Economy, 1(3).

Wray, L.R. (1999), Understanding Modern Money: The Key to Full Employment and Price Stability, Cheltenham, UK: Edward Elgar.

Wray, L.R. (2005), 'The ownership society: Social Security is only the beginning . .,' Public Policy Brief No. 82, Levy Economics Institute of Bard College, Annandale-on-Hudson, New York.

Wray, L.R. (2008), 'Lessons from the subprime meltdown', Challenge, March-April. 